\title{
Detection of High Concentrations of Organic Acids in Fish Emulsion and Their Role in Pathogen or Disease Suppression
}

\author{
Pervaiz A. Abbasi, George Lazarovits, and Suha Jabaji-Hare
}

First and second authors: Southern Crop Protection and Food Research Centre, Agriculture and Agri-Food Canada, 1391 Sandford Street, London, ON N5V 4T3, Canada; and third author: Plant Science Department, MacDonald Campus, McGill University, 21111 Lakeshore Rd., Ste-Anne-de-Bellevue, QC H9X 3V9, Canada.

Accepted for publication 4 December 2008.

\begin{abstract}
Abbasi, P. A., Lazarovits, G., and Jabaji-Hare, S. 2009. Detection of high concentrations of organic acids in fish emulsion and their role in pathogen or disease suppression. Phytopathology 99:274-281.

Fish emulsion (FE) added to a sandy-loam soil at 1 and $2 \%$ rates reduced the viability of Verticillium dahliae microsclerotia by 39 and $74 \%$ in 1 day, 87 and $98 \%$ in 3 days, and 95 and $99 \%$ in 6 days, respectively. The immediate kill of microsclerotia indicated that FE contains toxic substances. We found in FE high concentrations ( $400 \mathrm{mmol} / \mathrm{liter}$ ) of organic acids, including some known toxicants. Glycolic, acetic, formic, $n$-butyric, and propionic acids were the major organic acids detected in $\mathrm{FE}$ at the proportions of $52.5,26.9,7.9,7.2$, and $4.7 \%$, respectively. In solution assays, the viability of $V$. dahliae microsclerotia treated for $24 \mathrm{~h}$ in $1,2,5$, and $10 \% \mathrm{FE}(\mathrm{pH} 3.6$ to 3.0$)$ or a mixture of organic acids $(\mathrm{pH}$ 4.1 to 3.9) equivalent to the proportions in $\mathrm{FE}$ was reduced by 74, 94, 97,

6.0. The organic acids mixtures and formic $(0.025 \%)$ and acetic $(0.1 \%)$ acids were toxic to Pythium ultimum. A mixture of organic acids (1, 2, and $4 \%$ ) provided immediate protection of cucumber seedlings from damping-off in P. ultimum-infested muck and sandy-loam soils but not in peat-based mix. FE (1 and 2\%) provided immediate protection of cucumber seedlings from damping-off in an infested muck soil, and disease protection was consistent when planting was delayed for 7,14 , and 28 days after adding FE. FE (1, 2, and 4\%) did not provide immediate protection of cucumber seedlings from damping-off in a P. ultimuminfested peat-based mix; however, disease suppression was evident when planting was delayed for 7, 14, and 21 days after adding FE. Real-time polymerase chain reaction analyses of the peat-based mix indicated that the P. ultimum populations in the FE-amended mix declined over time. This study suggests that these organic acids in FE played a major role in pathogen or disease suppression, depending on the soil and substrate.
\end{abstract} and $99 \%$ or $81,91,98$, and $99 \%$, respectively. The viability of microsclerotia was increased when the treatment solutions were buffered to $\mathrm{pH}$
Additional keywords: organic soil amendment, volatile fatty acid.
Additions of organic materials to pathogen-infested soils or substrates have been reported to suppress plant diseases $(8,25$, 28,31-33) but the mechanisms of suppression were rarely investigated or understood. Any information on how organic amendments provide disease suppression is essential for optimizing and enhancing disease-reducing efficacy that these organic materials may provide (29). A general or long-term effect of organic soil amendments is their potential to enhance microbial activity, including biocontrol agents, leading to the establishment of natural disease suppressive conditions $(8,25,32,33)$. Organic amendments increase the activity and diversity of resident microbial communities by increasing the organic matter content of the amended soil (30) and, thereby, may provide a climate more favorable to natural biological control of soilborne plant pathogens.

Short-term effects may be more specific to a particular type of amendment that results in an immediate reduction of pathogen inoculum $(31,38,39)$. High nitrogenous and volatile fatty acid (VFA)-containing amendments are excellent examples displaying an almost immediate reduction in pathogen populations via shortlived toxic metabolites $(18,29,37,39)$. Products such as soymeal, poultry manure, meat and bone meal, and so on, when applied to soil in high quantities, are broken down by soil microbes and liberate large quantities of ammonia which, at neutral or acid $\mathrm{pH}$ levels, is converted to ammonium. However, at $\mathrm{pH}$ levels above 8.0 , ammonium is converted to the volatile gas ammonia $(29,38)$

Corresponding author: P. A. Abbasi; E-mail address: Pervaiz.Abbasi@agr.gc.ca

doi:10.1094/PHYTO-99-3-0274

(C) 2009 The American Phytopathological Society and, whereas ammonium is not toxic, ammonia is very toxic (38). In the course of nitrification ammonium is converted to nitrite which is not toxic at neutral $\mathrm{pH}$ but, at low $\mathrm{pH}(\leq 5.0)$ is converted to nitrous acid, which is a very potent biocide (38). The presence of these active products is highly dependent on soil organic matter content and soil $\mathrm{pH}$ and its buffering capacity (38). Volatile toxic compounds can also be produced by creating anaerobic and reducing conditions in the soil by incorporating fresh organic material such as broccoli or grass (11). Covering of the amended plots with plastic sheets enhances the concentration and the longevity of the toxicants in the soil profile (11).

Liquid swine manure (LSM) was found to provide disease relief by virtue of the presence in the manure of high concentrations of toxic VFAs, such as acetic, butyric, propionic, valeric, and other acids $(18,37)$. Only manures that contained sufficient quantities of these VFAs provided significant disease reduction and only in soils where the $\mathrm{pH}$ was $<5.0$, allowing for the biological activity of the acids $(18,37)$. In soils with $\mathrm{pH}$ levels $>6.0$, the VFAs exist as salts that have no biological activity (37). The effects of organic amendment suggests that both chemical and biological components of the amended soils can contribute to disease suppression $(1,14,19)$, and it is likely that several mechanisms contribute to activity simultaneously with some products in some soils.

Fish emulsions (FE) or fish-soluble nutrients are liquid byproducts of the fish-processing industry and have been used mainly as fertilizers $(10,15)$. FE was used in one study as a nutrient base for plant-growth-promoting rhizobacteria (21). We demonstrated that FE can also provide highly effective disease protection against some foliar (5) and soilborne diseases $(2,3)$. A 
preplant amendment of $\mathrm{FE}$ in various peat-based substrates or soils suppressed damping-off diseases caused by Rhizoctonia solani and Pythium aphanidermatum (2) and potato scab (3). The suppressing effect of FE was immediate in soil but not in peatbased substrates, and the effective rate of FE was also different in peat-based substrates and soils. This suggested that the mechanisms of suppression by FE may be different in peat-based substrate, organic or muck soil, and sandy-loam soils. The current study was undertaken to analyze FE for the presence of any toxic substances and investigate mechanisms of pathogen or disease suppression.

\section{MATERIALS AND METHODS}

Plant material, soil, and FE. Fungicide-free cucumber $(\mathrm{Cu}$ cumis sativus L. cv. Straight Eight) seed was purchased from William Dam Seeds Ltd., Flamborough, ON, Canada. A muck or organic soil (organic matter $50 \%, \mathrm{pH} 6.8$ ) naturally infested with P. ultimum, $P$. irregulare, and other Pythium spp. $(6,7)$ was collected from commercial vegetable fields near Holland Marsh, ON. As reported earlier, the average propagule density of Pythium spp. in the muck soil was $1.4 \times 10^{3} \mathrm{CFU} / \mathrm{g}$ soil (7) as determined by soil dilution plating on PARP medium (corn meal agar amended with $5 \mathrm{mg}$ of pimaricin, $250 \mathrm{mg}$ of ampicillin, $10 \mathrm{mg}$ of rifampicin, and $100 \mathrm{mg}$ of pentachloronitrobenzene), selective for isolating pythiaceous organisms (22). Sandy-loam soils (organic carbon 0.7 and $0.8 \%$; pH 6.2 and 7.1) used in laboratory microcosm assays and growth-room bioassays were from commercial potato fields near Alliston, ON (sites $\mathrm{M}$ and V2). No native Pythium populations were found in these sandy-loam soils. FE and fish meal (FM) samples used in this study were prepared from menhaden fish (Brevoortia tyrannus) and provided by Omega Protein, Houston, TX.

Verticillium dahliae germination assay. The toxicity of FE or FM to microsclerotia of Verticillium dahliae, the fungal pathogen that causes early dying of numerous plants (34), was determined in a sandy-loam soil (site $\mathrm{M}$ ) in a laboratory microcosm assay $(24,38)$. FE (1 and $2 \%$ or 1 and $2 \mathrm{~g} / 100 \mathrm{~g}$ of dry soil) and FM ( 0.5 and $1 \%$ or 0.5 and $1 \mathrm{~g} / 100 \mathrm{~g}$ of dry soil) were added to the soil at $10 \%$ moisture (mass/mass soil) in polyethylene bags and vigorously mixed. Aliquots $(20 \mathrm{~g})$ were then transferred to test tubes $(22$ by $150 \mathrm{~mm}$ ) and closed with plastic caps that allowed for air exchange. Freshly prepared microsclerotia produced as described previously (24) were mixed with acid-washed quartz sand at a ratio of $15 \mathrm{mg}$ of microsclerotia (106 to $250 \mu \mathrm{m}$ in diameter) per gram of sand (106 to $250 \mu \mathrm{m}$ in diameter). The sand:microsclerotia mixture was added to polyester mesh bags ( 8 to $10 \mathrm{mg} / \mathrm{bag}$ ) and the bags were placed in the tubes prior to addition of soil in order to ensure that soil surrounded the bag. The tubes were gently tapped to settle the soil and incubated in the dark at $24^{\circ} \mathrm{C}$. After 1,3 , and 6 days, three replicate bags for each treatment were removed and placed in a sandy-loam soil (site $\mathrm{M}$ ) at $10 \%$ moisture for 1 week prior to plating onto a semiselective medium (24) using an Anderson air sampler. Plates were incubated at $24^{\circ} \mathrm{C}$ in the dark for 2 weeks. The number of germinating microsclerotia was counted under a dissecting microscope from the first 100 from each plate and percent germination for each treatment was determined. Soil $\mathrm{pH}$ was determined by placing soil $(8 \mathrm{~g})$ and cold water $(40 \mathrm{ml})$ in plastic sacks. The sacks were sealed and the slurry mechanically disrupted (30 s) using a Stomacher homogenizer (Seward Medical, London), and the sacks were placed on an orbital shaker at $200 \mathrm{rpm}$ for $1 \mathrm{~h}$ at $4^{\circ} \mathrm{C}$, then removed from the cold, mechanically disrupted again, allowed to sit at room temperature for $1 \mathrm{~h}$, and the $\mathrm{pH}$ determined. The experiment was repeated once.

Analysis of organic acids in FE. The concentration of organic acids in FE samples was determined by chemical suppression ion exclusion chromatography and conductivity detection (Dionex model 100; Dionex Corp., Sunnyvale, CA) as described previously (37). FE samples were diluted 10 and 100 times with Millipore distilled water. The diluted samples were centrifuged for $10 \mathrm{~min}$ at $10,600 \times g$ to remove particulates and $40 \mu \mathrm{l}$ of solution was injected to the ion chromatograph by a refrigerated autosampler. The chromatograph was equipped with an IonPac ICE-AS1 analytical column and AMMS ICE II chemical suppressor (Dionex Corp.). The identity of individual organic acids was confirmed by running standards.

Toxicity of organic acids from FE. A mixture of organic acids was prepared by adding individual organic acid components at the proportions found in FE (Table 1) to a final concentration of $\approx 400 \mathrm{mmol} /$ liter. The stock mixture of organic acids was stored in a refrigerator at $4{ }^{\circ} \mathrm{C}$ until use. Toxicity of the organic acids mixture to $P$. ultimum culture plugs and $V$. dahliae microsclerotia was determined in solution assays. The mixture of organic acids and FE was diluted with sterile double-distilled water $\left(\mathrm{ddH}_{2} \mathrm{O}\right)$ to the final concentrations of $1,2,5$, and $10 \%$ (vol/vol) immediately before use and their $\mathrm{pH}$ was determined with a $\mathrm{pH}$ meter. One set of $\mathrm{FE}$ and organic acid solutions was buffered to $\mathrm{pH} 6.0$ with citric acid-NaOH buffer. A nonbuffered water control ( $\mathrm{pH} 6.8$ ) and a water control buffered to $\mathrm{pH} 4.0$ with citric acid- $\mathrm{NaOH}$ were included as well. The treatment solutions $(5 \mathrm{ml})$ were transferred to 12-ml sterile culture tubes (three per treatment) and three mesh bags containing $V$. dahliae microsclerotia were submerged in each of the three replicate tubes per treatment. In the case of $P$. ultimum, three 5-mm plugs from a 48-h-old culture were submerged only in organic acid solutions in each of the three replicate tubes per treatment. The tubes were capped and incubated for $24 \mathrm{~h}$ in the dark at $24^{\circ} \mathrm{C}$. The culture plugs or mesh bags were retrieved from the solutions, rinsed twice with sterile distilled water, and dried in a laminar flow hood under sterile conditions for 2 to $3 \mathrm{~h}$. The culture plugs were plated (one per plate) immediately in the center of potato-dextrose agar (PDA) plates and mesh bags were placed in a sandy-loam soil for 1 week prior to plating onto soil-pectate-tertitol agar as described above. The PDA plates were incubated at $24^{\circ} \mathrm{C}$ in an incubator and growth of $P$. ultimum was recorded every day for 1 week. The number of germinating microsclerotia was counted under a dissecting microscope from each plate and percent germination for each treatment was determined as described above.

Toxicity of organic acids mixture to P. ultimum was also tested in PDA medium. The filter-sterilized mixture of organic acids was mixed with autoclaved molten PDA medium at $45^{\circ} \mathrm{C}$ to final concentrations of 1,2 , and $4 \%$ ( $\mathrm{vol} / \mathrm{vol})$, and the amended medium was poured into $9-\mathrm{cm}$ petri plates and allowed to solidify. Plates

TABLE 1. Concentration of organic acids in fish emulsion (FE) samples determined with chemical suppression ion exclusion chromatography and conductivity detection $^{\mathrm{a}}$

\begin{tabular}{|c|c|c|c|c|c|c|c|c|}
\hline \multirow[b]{2}{*}{$\mathrm{FE}$} & \multicolumn{8}{|c|}{ Concentration of organic acids (mmol/liter) } \\
\hline & Glycolic acid & Formic acid & Acetic acid & Propionic acid & $n$-Butyric acid & iso-Butyric acid & iso-Valeric acid & Total \\
\hline 2005 & 200.0 & 38.3 & 113.0 & 14.2 & 34.0 & 1.0 & 1.7 & 402.2 \\
\hline 2006 & 225.0 & 25.3 & 104.8 & 24.0 & 24.6 & 1.4 & 2.3 & 407.4 \\
\hline
\end{tabular}

${ }^{a}$ FE samples were diluted 10 and 100 times before analyses and particulates were removed by centrifugation for $10 \min$ at $10,600 \times g$. 
were inoculated with 5-mm plugs of a freshly growing culture of P. ultimum and incubated at $24^{\circ} \mathrm{C}$ in an incubator, and colony diameter was measured every day for 1 week. Toxicity of individual organic acids such as acetic $(0.025,0.05$, and $0.1 \%)$, formic $(0.025$ and $0.05 \%)$, and glycolic $(0.05,0.1$, and $0.15 \%)$ acids to $P$. ultimum was also tested in PDA medium as described above.

Growth-room bioassays. The efficacy of FE added as a preplant amendment to a peat-based mix artificially infested with soil inoculum of $P$. ultimum or a muck soil naturally infested with Pythium spp. to suppress damping-off of cucumber seedlings was determined in a growth room as described previously (2). The soil inoculum of $P$. ultimum produced as described previously (2) had an average propagule density of $2 \times 10^{3} \mathrm{CFU} / \mathrm{g}$ of soil as determined by soil-dilution plating on PARP medium (22). The amount of inoculum required to give more than $80 \%$ disease incidence within 2 weeks after planting was determined in preliminary experiments. FE (1, 2, or $4 \%$ mass/mass) was incorporated into the infested peat-based mix or soil in plastic bags. The contents were mixed thoroughly, and loosely tied bags were incubated at $24^{\circ} \mathrm{C}$ in darkness. At day $1,7,14,21$, or 28 , the amended mix or soil from the bags was dispensed into $10-\mathrm{cm}$-diameter plastic pots, and eight cucumber seed were planted in each of the five replicate pots per treatment. Pots were kept in a growth room ( $15 \mathrm{~h}$ of fluorescent light at $22^{\circ} \mathrm{C}$ and $9 \mathrm{~h}$ of darkness at $19^{\circ} \mathrm{C}$ ) and arranged in a completely randomized design. They were watered as required to maintain appropriate moisture level for growth and disease development. Plants were rated 2 weeks after sowing for damping-off using a 1-to-4 scale where $1=$ healthy, $2=$ yellowing of stem or root, $3=$ plant dead, and $4=$ seedling not emerged. Data were also expressed as percent healthy seedlings. All experiments were repeated once.

In separate trials, the efficacy of the mixture of organic acids equivalent to the proportions found in FE to suppress Pythium damping-off of cucumber seedlings was determined in a muck soil, sandy-loam soil (site V2), and peat-based mix artificially infested with soil inoculum of $P$. ultimum. The mixtures of organic acids $(1,2$, and $4 \%$ vol/mass) were thoroughly mixed with the infested soils or peat-based mix and incubated for $24 \mathrm{~h}$ before planting cucumber seed as described above. Plants were main-

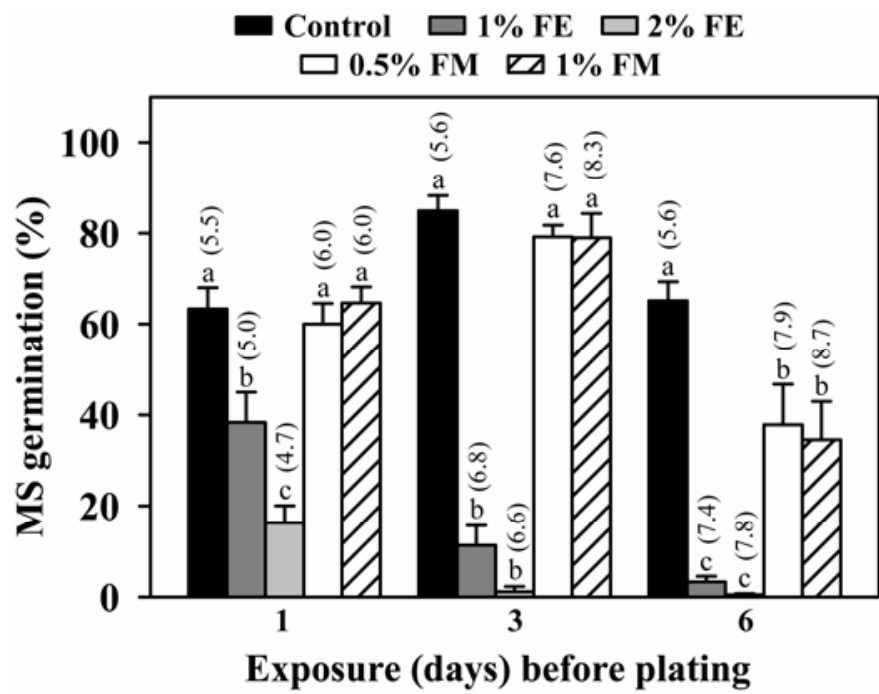

Fig. 1. Effect of fish emulsion (FE) added to site $M$ soil on germination of Verticillium dahliae microsclerotia (MS) and soil $\mathrm{pH}$. MS were placed in the soil at day zero and removed after 1, 3, and 6 days. Percent germination was determined by plating MS onto semiselective medium. Means ( \pm standard error) are average of two experiments $(n=6)$. The numbers enclosed in brackets over the bars are $\mathrm{pH}$ values. Bars with the same letter within each sampling time do not differ significantly for MS germination according to Fisher's protected least significant difference test at $P \leq 0.05$. tained in a growth room for disease development and rated for damping-off severity as described above.

Real-time polymerase chain reaction assay. After rating cucumber plants, the peat-based mix samples were analyzed by real-time polymerase chain reaction (PCR) for quantification of $P$. ultimum using species-specific primer set K1/K3 (23), which amplifies an amplicon of $670 \mathrm{bp}$ specific for $P$. ultimum. Three subsamples $(0.1 \mathrm{~g}$ each $)$ of the freeze-dried peat-based mix from each of three replicate pots selected arbitrarily were taken for DNA extraction. DNA was extracted with Ultra Clean soil DNA purification kit (Mo Bio Laboratories Inc., Carlsbad, CA) according to the manufacturer's protocol.

External standards for quantification consisted of six serially diluted $P$. ultimum genomic DNA (23.1, 2.31, 0.231, 0.0231, 0.00231 , and $0.000231 \mathrm{ng} / \mu \mathrm{l})$. All standards were prepared in $10 \mathrm{mM}$ Tris- $\mathrm{HCl}(\mathrm{pH} \mathrm{7.4)}$ and included in triplicates in each realtime PCR quantification run to construct a standard curve and calculate quantities of $P$. ultimum DNA in the unknown samples. Quantification algorithms (Mx300PTM real-time PCR system software, version 2.0; Stratagene, La Jolla, CA) were used for the calculation of DNA amounts. Standard curves were constructed from duplicate standards using their cycle threshold numbers, PCR cycle numbers at which the fluorescence of the sample exceeds the background fluorescence, and the known starting DNA amounts.

Quantitative PCR was performed using Mx3000P (Stratagene, Cedar Creek) and SYBR Green QPCR master mix (Stratagene) following the manufacturer's recommendations. Each run included a negative control and a standard curve. Two technical replicates were performed using two different master mixes. Reactions were prepared in optical strip tubes Mx3000p using the following master mix: $10 \mu \mathrm{l}$ of Brilliant SYBR Green PCR master mix, $0.30 \mu \mathrm{l}$ of ROX reference dye, $1 \mu \mathrm{l}$ of $1 / 10$ diluted DNA template, $2 \mu \mathrm{l}$ of each $\mathrm{K} 1$ and $\mathrm{K} 3$ primer $(100 \mathrm{nM})$ and $2.2 \mu \mathrm{l}$ of sterile $\mathrm{dd}_{2} \mathrm{O}$. Thermocycling was performed with an initial denaturation at $95^{\circ} \mathrm{C}$ for $10 \mathrm{~min}$, followed by 50 cycles of $95^{\circ} \mathrm{C}$ for $30 \mathrm{~s}, 58^{\circ} \mathrm{C}$ for $30 \mathrm{~s}$, and $72^{\circ} \mathrm{C}$ for $30 \mathrm{~s}$. The specificity of the quantitative real-time PCR single products was confirmed by the melting curve analysis and by gel electrophoresis on $1.5 \%$ agarose gel. Each run included a negative control and was repeated twice on two different days (two technical replicates).

Statistical analyses. The data were subjected to analysis of variance using MINITAB statistical software (version 13.0; Minitab Inc., State College, PA) and, if $P$ values indicated a significant difference $(P \leq 0.05)$, means were separated by Fisher's protected least significant different test. Disease severity data were analyzed using Jandel SigmaStat statistical software (Jandel Scientific, San Rafael, CA). Data were subjected to one-way analysis of variance using Kruskal-Wallis nonparametric test statistics and means were separated according to Student-Newman-Keuls test. P. ultimum DNA quantification data were $\log _{10}$ transformed and two-way analysis of variance was performed using the general linear model procedure of SAS (35).

\section{RESULTS}

Effect of FE on viability of $\boldsymbol{V}$. dahliae microsclerotia. Addition of increasing rates of $\mathrm{FE}$ to a sandy-loam soil from a commercial potato field (site $\mathrm{M}$ ) reduced the germination of $V$. dahliae microsclerotia compared with the control treatment (Fig. 1 ). The $1 \%$ rate of FE reduced MS germination by $39 \%$ after day $1,87 \%$ after day 3 , and $95 \%$ after 6 days of exposure over the control (Fig. 1). The $2 \%$ rate of FE significantly reduced microsclerotia germination by $74 \%$ over the control after 1 day of exposure (Fig. 1). After 3 and 6 days of exposure to the $2 \% \mathrm{FE}$ treatment, more than $99 \%$ of microsclerotia did not germinate compared with the control (Fig. 1). On the other hand, exposure of microsclerotia for 1 and 3 days to the sandy-loam soil amended 
with 0.5 and $1 \%$ rates of FM did not affect their germination; however, after 6 days of exposure, both rates significantly reduced microsclerotia germination by 42 and $47 \%$ over the control (Fig. 1). The 1 and $2 \%$ FE treatments reduced the soil $\mathrm{pH}$ by 0.8 and $1.1 \log$ units over the control (from 5.9 in the control to 5.1 and 4.8) immediately after the amendment incorporation, and $\mathrm{pH}$ remained low at the same levels with both rates of FE after 1 day (Fig. 1). Both FE rates increased the soil $\mathrm{pH}$ to more than $1.0 \mathrm{log}$ unit after 3 days. Soil $\mathrm{pH}$ was further increased from 5.6 in the control to 7.4 and 7.8 by 1 and $2 \%$ FE rates after 6 days. Both 1 and $2 \%$ rates of FM did not affect soil $\mathrm{pH}$ immediately after incorporation but increased $\mathrm{pH}$ by $0.5 \log$ units after day $1,2.0$ to $2.7 \log$ units after day 3 , and 2.3 to $3.1 \log$ units after day 6 over the control (Fig. 1).

Organic acids in FE. The average concentration of total organic acids in the FE was $\approx 400 \mathrm{mmol} /$ liter (Table 1 ). A chromatogram of organic acids fingerprints of FE is shown in Figure 2. More than half of the total organic acids concentration was of glycolic acid. Acetic, formic, $n$-butyric, and propionic acids were other major organic acids present in FE at the proportions of 26.9, $7.9,7.2$, and $4.7 \%$ of total organic acids, respectively (Table 1). Minor concentrations ( 0.9 to $2.0 \mathrm{mmol} / \mathrm{liter})$ of iso-butyric, $n$-valeric, and iso-valeric acids were also detected in FE samples. We also analyzed an FE sample from Brazil that had a similar

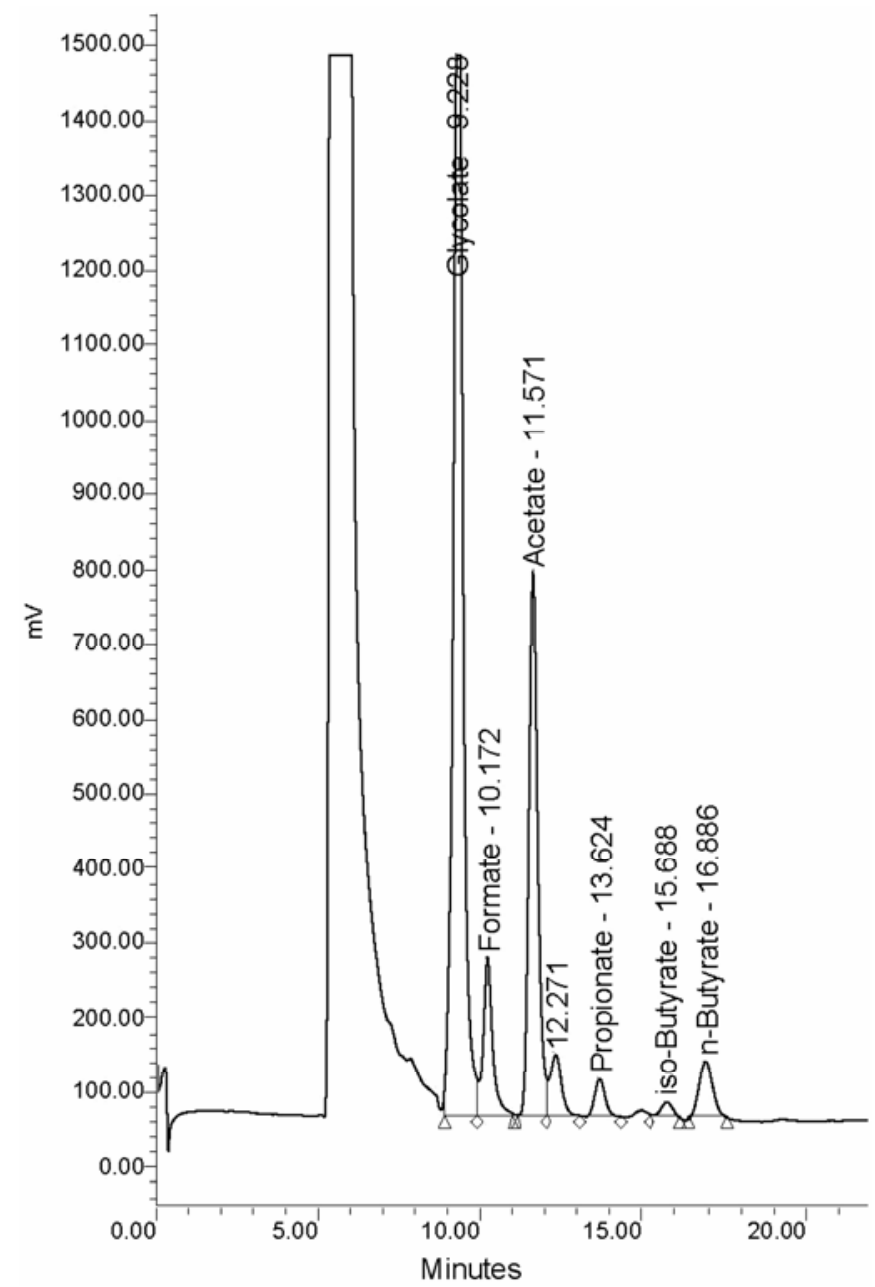

Fig. 2. Chromatogram of volatile and nonvolatile organic acids of 100 times diluted fish emulsion (FE) sample. FE samples were diluted 10 and 100 times before analyses. Particulates were removed by centrifugation (10 $\mathrm{min}$ at $10,600 \times g$ ) and the concentration of individual organic acid determined using chemical suppression ion exclusion chromatography and conductivity detection (Dionex model 100; Dionex Corp., Sunnyvale, CA). The chromatograph was equipped with an IonPac ICE-AS1 analytical column and AMMS ICE II chemical suppressor (Dionex Corp.). chromatogram; however, the concentration of organic acids was much higher $(1,000 \mathrm{mmol} / \mathrm{liter})$ compared with our FE sample (data not shown).

Toxicity of organic acids from FE. In solution assays, the viability of $V$. dahliae microsclerotia treated for $24 \mathrm{~h}$ in $1,2,5$, and $10 \% \mathrm{FE}$ or a mixture of organic acids equivalent to the proportions in FE was reduced by $74,94,97$, and $99 \%$ or 81,91 , 98 , and $99 \%$, respectively, over the control (Fig. 3). The viability of microsclerotia was similar in the citric acid- $\mathrm{NaOH}$-buffered water control $(\mathrm{pH} 4.0)$ and the nonbuffered water control $(\mathrm{pH}$ 6.8). The pHs of organic acids or FE solutions were 4.0, 3.6, 3.2, and 3.0 or $4.4,4.0,3.9$, and 3.8 , respectively. In the $\mathrm{pH} 6.0$ buffered FE and equivalent organic acid solutions, the viability of microsclerotia was increased compared with in the nonbuffered FE and organic acid solutions (Fig. 3). Only the $10 \% \mathrm{pH} 6.0-$ buffered treatment solutions significantly reduced the viability of microsclerotia by 54 to $57 \%$ compared with the control (Fig. 3).

The culture plugs treated with organic acid solutions did not grow, and no growth was observed on PDA plates after 1 week, whereas control plugs submerged in sterile $\mathrm{ddH}_{2} \mathrm{O}$ or buffer controls grew and fully covered the plates after 2 days. Formic acid and acetic acid were inhibitory to $P$. ultimum when amended in the PDA growth medium. There was no growth of the pathogen on plates after 7 days of incubation with the lowest concentration $(0.025 \%)$ of formic acid compared with the control plates, which were fully covered after 2 days of incubation. The maximum linear growth attainable in these plates was $9 \mathrm{~cm}$. There were 3.6 and $1.5 \mathrm{~cm}$ of growth of the pathogen on plates amended with 0.025 and $0.05 \%$ acetic acid, respectively, but no growth on plates amended with $0.1 \%$ acetic acid. Glycolic acid was not toxic to $P$. ultimum in the PDA medium at up to $0.15 \%$ concentration tested.

Effect of organic acids mixture on damping-off of cucumber seedlings. In muck and sandy-loam soils artificially infested with soil inoculum of $P$. ultimum, the mixture of organic acids equivalent to the proportions found in FE provided immediate protection of cucumber seedlings from damping-off in a dose-response manner (Fig. 4). Higher concentrations (2 and 4\%) of organic acids mixtures were more effective than a lower concentration (1\%). There were more than two-, three- to four-, or four- to fivefold increases in the percentage of healthy seedlings with 1,2 , or $4 \%$ mixtures of organic acids, respectively, over the control (Fig.

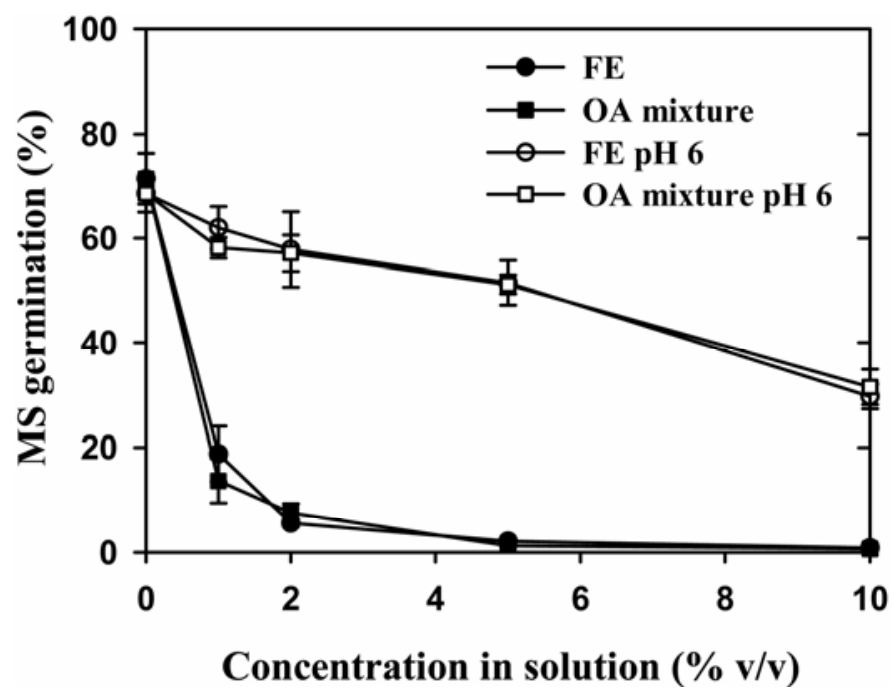

Fig. 3. Effect of fish emulsion (FE) and a mixture of volatile and nonvolatile organic acids (OA) on the germination of Verticillium dahliae microsclerotia (MS) in solution bioassays. The OA mixture was prepared with concentrations of individual OA components as found in FE. MS were submerged in the buffered $(\mathrm{pH} 6)$ and nonbuffered solutions for $24 \mathrm{~h}$ and percent germination was determined by plating MS onto semiselective medium. Means $( \pm$ standard error) are average of two experiments $(n=6)$. 
4). The reduction in damping-off severity by increasing concentrations of organic acid mixtures followed a similar trend in both soils, with 20 to $53 \%$ reduction of disease severity over the control (Fig. 4). None of the concentrations of organic acids mixtures provided immediate protection of cucumber seedlings against damping-off in an infested peat-based mix (Fig. 4). No protection was observed even when the planting was delayed for 7 or 14 days after adding the organic acid mixtures to the infested peat-based mix (data not shown).

Effect of FE on damping-off of cucumber seedlings. The naturally infested muck soil from a commercial field had a high damping-off potential on cucumber seedlings. More than $75 \%$ of the cucumber plants in the nonamended control were diseased, with an average disease severity rating of 3.4 (Fig. 5A and B). After 1 day of incorporation in muck soil, both 1 and $2 \%$ rates of FE were effective in improving the healthy seedlings by 31 and $50 \%$, respectively (Fig. 5A), and decreasing the disease severity by 1.2 to 1.6 units (Fig. 5B) over the control. The improvement in healthy seedlings and reduction in disease severity were consistent when planting was delayed for 1,2 , and 4 weeks after FE incorporation. When seed were planted after 1 week of FE incorporation, the percentage of healthy seedlings was increased by 63 to $71 \%$ (Fig. 5A) and disease severity decreased by 1.9 to 2.2 units (Fig. 5B) over the control. When planting was delayed for 2 week after $\mathrm{FE}$ incorporation, the percentage of healthy seedlings was increased by 56 and $65 \%$ (Fig. 5A) and disease severity decreased by 1.6 and 2.0 units (Fig. 5B) with the 1 and $2 \% \mathrm{FE}$ treatments over the control, respectively. When planting was delayed for 4 weeks after FE incorporation, the percentage of healthy seedlings was improved by 53 to $59 \%$ (Fig. 5A) and disease severity decreased by 1.6 to 1.9 units (Fig. 5B) with the FE treatments over the control.

Peat-based mix artificially infested with soil inoculum of $P$. ultimum was very pathogenic to cucumber throughout the 4-week incubation period. More than $80 \%$ of the cucumber plants in the control were diseased, with an average disease severity rating of
3.4 (Fig. 6A and B). When the infested mix was amended with 1 , 2 , and $4 \%$ rates of $\mathrm{FE}$ and incubated for 1, 7, 14, and 21 days prior to planting cucumber seed, damping-off suppression appeared over time. There was no protection of cucumber seedlings from damping-off when seed were planted 1 day after FE incorporation in the infested mix. The percentage of the healthy seedlings and disease severity were similar to the control (Fig. 6A and B). When planting was delayed for 7, 14, or 21 days after incubation, damping-off suppression become evident in the FE-amended peatbased mix. When seed were planted after 7 days of incubation, the percentage of healthy seedlings was increased from $<15 \%$ in the control to $>75 \%$ in the FE treatments (Fig. 6A), with a decrease in disease severity ratings over the control (Fig. 6B). The FE-amended peat-based mix was consistently suppressive against Pythium damping-off after 14 and 21 days of incubation (Fig. 6A and B).

Real-time PCR analyses of the P. ultimum DNA extracted from the peat-based mix indicated that all FE concentrations significantly reduced the pathogen compared with the control (Fig. 7A). The amount of $P$. ultimum DNA was similar in the control and FE treatments after 1 day of incubation of the amended peat-based mix (Fig. 7B). The amount of $P$. ultimum DNA significantly decreased in the FE-treated peat-based mix compared with in the control after 7, 14, and 21 days of incubation (Fig. 7B). The $\mathrm{K} 1 / \mathrm{K} 3$ primer set amplified a single expected amplicon of $670 \mathrm{bp}$ and a melting point temperature of $81.6 \pm 0.5^{\circ} \mathrm{C}$ as determined by the melting curve analysis. Quantification showed a high linearity $\left(R^{2}=0.97\right)$ between $\log _{10}$ values of DNA and real-time PCR threshold cycles over the range of DNA concentration examined, demonstrating a high reproducibility among the replicates tested and the accuracy of the PCR quantification assay.

\section{DISCUSSION}

This is first study demonstrating that FE contains large quantities of organic acids that are toxic to pathogens and may have a



Fig. 4. Effect of a mixture of volatile and nonvolatile organic acids (OA) as a preplant amendment on $\mathbf{A}$, percent healthy and $\mathbf{B}$, damping-off severity of cucumber seedlings in a muck soil or sandy-loam soil or peat-based mix artificially infested with soil inoculum of Pythium ultimum. The OA mixture was prepared with concentrations of individual OA components as found in FE and mixed with the infested soil or mix. After incubation at $24^{\circ} \mathrm{C}$ in the dark for $24 \mathrm{~h}$, cucumber seed were planted and incubated in a growth room. Plants were rated 2 weeks later for damping-off disease using a 1-to-4 rating scale. Means ( \pm standard error) are the average of two experiments. Means within each planting time followed by the same letter do not differ significantly according to A, Fisher's protected least significant difference test or $\mathbf{B}$, Student-Newman-Keuls test at $P \leq 0.05$. 
role in disease suppression by FE, depending on soils or substrates. The concentration of organic acids reported here in FE ( $\approx 400 \mathrm{mmol} / \mathrm{liter}$ ) was significantly higher than the concentration of organic acids found in LSM (18). Even higher concentrations $(1,000 \mathrm{mmol} / \mathrm{liter})$ of organic acids were detected in FE samples received from a Brazilian company (unpublished data). It is likely that these organic acids are produced during anaerobic decomposition of sugars or proteins present in the FE. More than half of the total organic acid concentration in FE was of glycolic acid. Glycolic acid is not classified as a volatile organic acid but it has antimicrobial properties at higher concentrations. Glycolic acid has been patented as a plant-growth-promoting agent (27) and is widely used as an ingredient in skin care products. In this study, glycolic acid $(\leq 0.15 \%)$ did not inhibit the growth of $P$. ultimum in PDA agar medium; however, it enhanced the percentage of healthy cucumber seedlings in a muck soil infested with Pythium spp. (data not shown). Glycolic acid is found in sugary plants such as sugarcane and is also manufactured synthetically. Its presence in FE at very high concentrations needs further investigation.

Acetic, formic, $n$-butyric, and propionic acids are the major toxic volatile organic acids in FE. All these organic acids, except glycolic and formic acids, have also been found in LSM and were considered to be a major factor associated with disease reduction by $\operatorname{LSM}(18,37)$. FE, in contrast, contains high levels of formic acid (7.9\% of the total organic acids) and formic acid was found to be seven times more toxic to pathogens such as $V$. dahliae

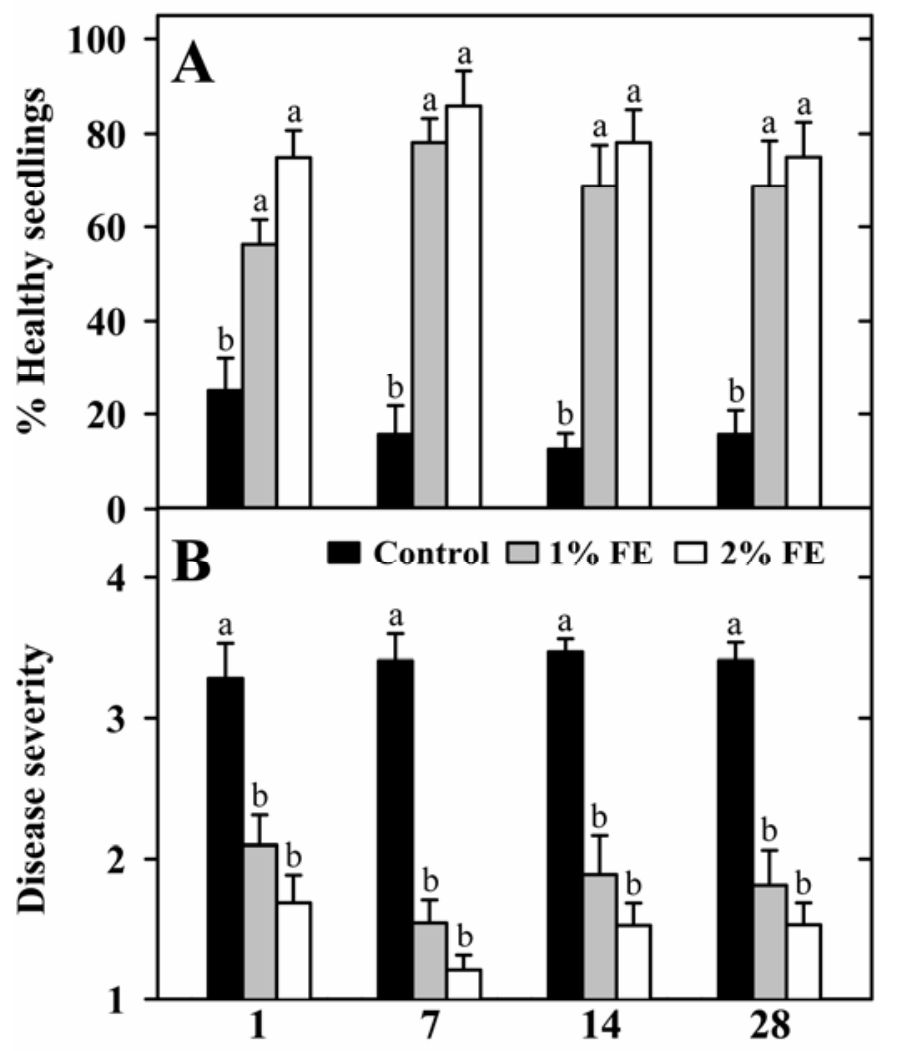

Incubation (days) before planting

Fig. 5. Effect of fish emulsion (FE) as a preplant amendment on A, percent healthy seedlings and $\mathbf{B}$, damping-off severity of cucumber seedlings in naturally-infested muck soil from Holland Marsh, ON. FE (mass/mass soil) was incorporated into the infested soil and incubated at $24^{\circ} \mathrm{C}$ in the dark. After $1,7,14$, and 28 days, cucumber seed were planted and incubated in a growth room. Plants were rated 2 weeks later for damping-off disease using a 1-to-4 rating scale. Means ( \pm standard error) are the average of two experiments. Means within each planting time followed by the same letter do not differ significantly according to A, Fisher's protected least significant difference test or $\mathbf{B}$, Student-Newman-Keuls test at $P \leq 0.05$. compared with acetic acid (37). Higher concentrations of these volatile acids can be toxic to crop plants (20), and some of these organic acids are also known to kill fungal plant pathogens (13, $17,26,36)$ and plant-parasitic nematodes $(12,13)$. Organic acids from freshly composted municipal wastes have been implicated in suppression of infection of citrus seedlings by Phytophthora nicotianae (40). Although volatile organic acids are directly toxic to pathogens in solution or laboratory assays, their effectiveness for disease suppression under field conditions should be investigated.

A mixture of organic acids equivalent to the proportions found in FE and acetic and formic acids were toxic to Pythium ultimum in solution assays in this study. The increasing concentrations of a mixture of organic acids also suppressed damping-off of cucumber seedlings in a muck and sandy-loam soils but not in a peatbased mix. Similarly, comparable rates of FE also provided immediate protection of cucumber seedlings from damping-off within 1 day after incorporation of FE in an infested muck soil (2). However, damping-off suppression of cucumber seedlings in a peat-based mix was achieved only after planting was delayed for a week or more after adding FE to the pathogen-infested mix. Real-time PCR analyses of the peat-based mix also indicated no immediate effect of FE on $P$. ultimum populations. It is less likely that organic acids from FE played a role in delayed suppression of $P$. ultimum damping-off in a peat-based mix. This specificity of organic acids for disease suppression in various soils or substrates should be further investigated at various inoculum levels.

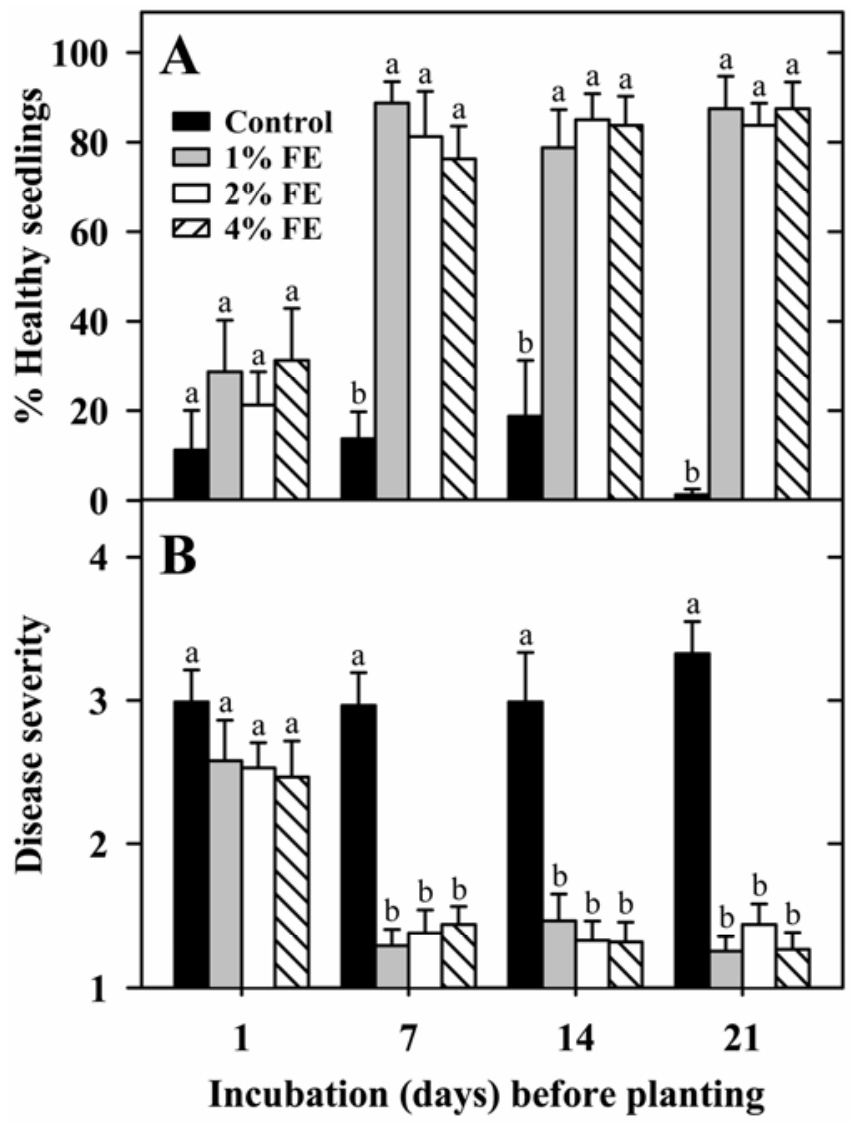

Fig. 6. Effect of fish emulsion (FE) as a preplant amendment on $\mathbf{A}$, percent healthy and $\mathbf{B}$, damping-off severity of cucumber seedlings in a peat-based mix artificially infested with soil inoculum of Pythium ultimum. FE (mass/mass mix) was incorporated into the infested mix and incubated at $24^{\circ} \mathrm{C}$ in the dark. After 1, 7, 14, and 21 days, cucumber seed were planted and incubated in a growth room. Plants were rated 2 weeks later for damping-off disease using a 1-to-4 rating scale. Means ( \pm standard error) are the average of two experiments. Bars with the same letter within each planting time do not differ significantly according to Fisher's protected least significant difference test at $P \leq 0.05$. 
The rapid reduction in the viability of $V$. dahliae microsclerotia in a sandy-loam soil with FE was likely due to the toxicity of these organic acids. More than $98 \%$ of $V$. dahliae microsclerotia did not germinate after exposure to $2 \% \mathrm{FE}$ for 3 days. When $V$. dahliae microsclerotia were treated with the mixture of organic acids at the proportions found in FE in solution assays, the viability of microsclerotia was significantly reduced and was comparable with that seen with equivalent rates of FE. The viability of microsclerotia was increased when the treatment solutions (FE and mixture of organic acids) were buffered to $\mathrm{pH} 6.0$ with $\mathrm{NaOH}$-citrate buffer. This clearly suggests that organic acids in FE play an important role in pathogen suppression. The biological activity of VFAs is maximized under acidic conditions (37); therefore, it is possible that VFA toxicity may have been one of the mechanisms of disease reduction by FE in the low $\mathrm{pH}$ soils (3).

Disease suppression by FE in various soils or substrates as reported in this study or previous studies $(2,3)$ was certainly not due to toxicities of ammonia or nitrous acid. The rates of FE used in sandy-loam soil were not high enough to generate ammonia at the toxic concentration, and even high rates of FE could not have generated toxic concentration of ammonia due to the high buffering capacity of peat-based mix and muck soil. The $\mathrm{pH}$ of the FEtreated peat-based mix or muck soil did not substantially increase or decrease compared with their respective controls (data not
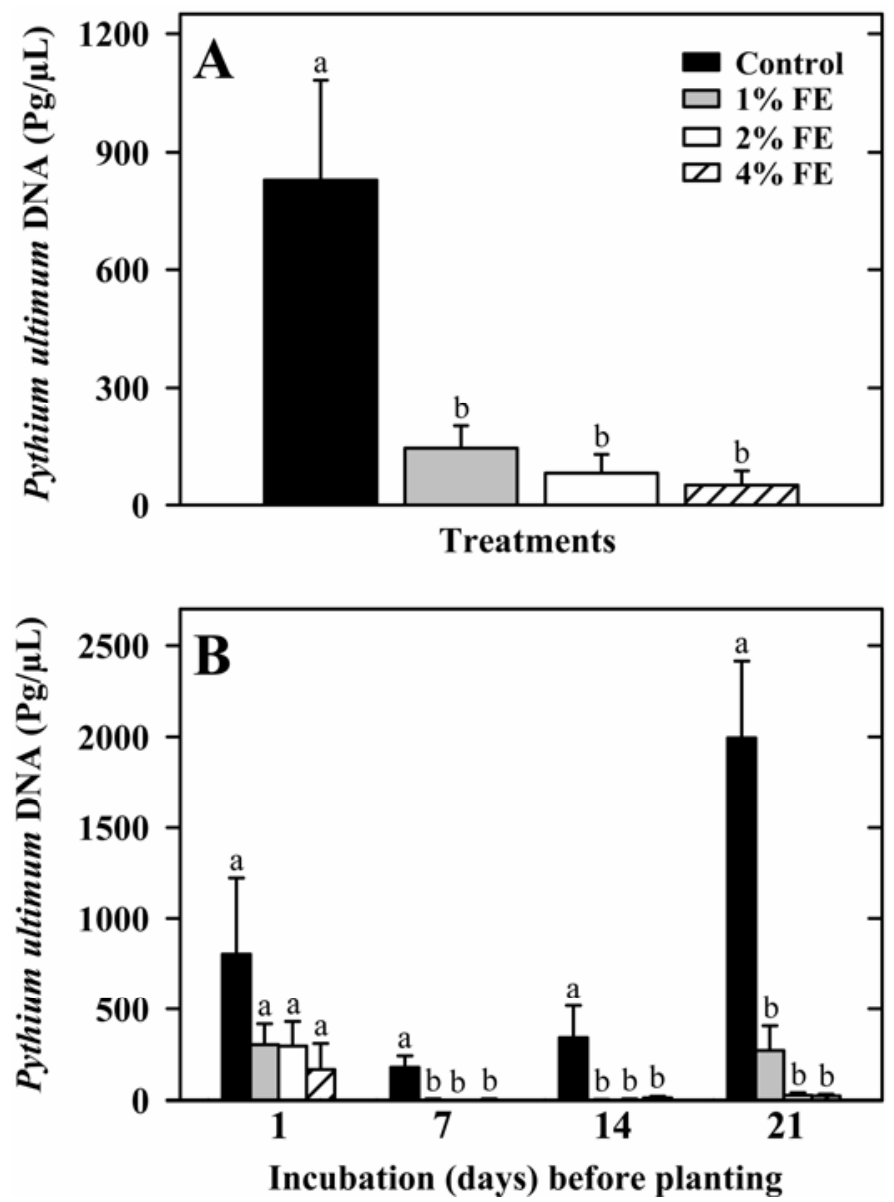

Fig. 7. A and B, Real-time polymerase chain reaction (PCR) analyses of a peat-based mix infested with Pythium ultimum and amended with fish emulsion (FE). FE (mass/mass mix) was incorporated into the infested mix and incubated for $1,7,14$, and 21 days at $24^{\circ} \mathrm{C}$ in the dark before planting cucumber seed. After rating plants, three subsamples of peat-based mix from each of three replicate pots were taken for DNA extraction and PCR analyses. The DNA of $P$. ultimum was estimated based on external standards. Bars with the same letter (B, within each planting time) do not differ significantly according to Fisher's protected least significant difference test at $P \leq 0.05$. shown). FM, on the other hand, did not immediately affect the germination of $V$. dahliae microsclerotia in a sandy-loam soil but the effect started to appear after 6 days. FM, which does not contain organic acids, is a high nitrogenous amendment and it is known that nitrogen transformation products, such as ammonia and nitrous acid, play a major role in reducing the viability of $V$. dahliae microsclerotia (38).

In conclusion, FE contains large quantities of organic acids that are toxic to plant pathogens and may have a role in disease suppression, depending on the soil and substrate. Immediate pathogen or disease suppression in sandy-loam or muck soils suggests that organic acids may play a major role. In addition, the role of biological control in the suppression of soilborne pathogens or diseases in the FE-amended soil or substrate cannot be ruled out. Biological control stimulated by the addition of organic material into potting substrates or agricultural soils has been attributed as a mechanism of disease suppression in some studies $(2,4,8,9,16$, 19). The rates of FE providing effective disease control in the field (3) may not be economical for every crop and every soil. However, it may be economical if the disease control effect lasts for multiple years after a single FE application. In order to maximize the pathogen or disease suppression effect of organic acids, FE should be applied to the soils with low $\mathrm{pH}$ and low buffering capacity.

\section{ACKNOWLEDGMENTS}

We thank B. Weselowski, E. Seip, H. Khan, I. Lalin, J. Park, L. Knezevich, N. Korba, M. Braun, and P. Martin for their technical assistance. This research was funded by grants from NSERC Bio-control Network, Omega Protein, and the Agriculture and Agri-Food Canada Matching Investment Initiative.

\section{LITERATURE CITED}

1. Abbasi, P. A., Al-Dahmani, J., Sahin, F., Hoitink, H. A. J., and Miller, S. A. 2002. Effect of compost amendments on disease severity and yield of tomato in conventional and organic production systems. Plant Dis. 86:156-161.

2. Abbasi, P. A., Conn, K. L., and Lazarovits, G. 2004. Suppression of Rhizoctonia and Pythium damping-off of radish and cucumber seedlings by addition of fish emulsion to peat mix or soil. Can. J. Plant Pathol. 26:177-187.

3. Abbasi, P. A., Conn, K. L., and Lazarovits, G. 2006. Effect of fish emulsion pre-plant soil amendment on Verticillium wilt, common scab, and tuber yield. Can. J. Plant Pathol. 28:509-518.

4. Abbasi, P. A., Conn, K. L., and Lazarovits, G. 2007. Managing soilborne diseases of vegetable crops with a pre-plant soil or substrate amendment of a corn distillation product. Biocontrol Sci. Technol. 17:331-344.

5. Abbasi, P. A., Cuppels, D. A., and Lazarovits, G. 2003. Effect of foliar applications of neem oil and fish emulsion on bacterial spot and yield of tomatoes and peppers. Can. J. Plant Pathol. 25:41-48.

6. Abbasi, P. A., and Lazarovits, G. 2005. Effects of AG3 phosphonate formulations on incidence and severity of Pythium damping-off of cucumber seedlings under growth room, microplot, and field conditions. Can. J. Plant Pathol. 27:420-429.

7. Abbasi, P. A., and Lazarovits, G. 2006. Seed treatment with phosphonate (AG3) suppresses Pythium damping-off of cucumber seedlings. Plant Dis. 90:459-464.

8. Abbasi, P. A., and Lazarovits, G., and Conn, K. L. 2008. Enhancing biological control of soilborne plant diseases by organic soil amendments. Pages 319-343 in: Plant-Microbe Interactions. E. A. Barka and C. Clément, eds. Research Signpost, Kerala, India.

9. Abbasi, P. A., Riga, E., Conn, K. L., and Lazarovits, G. 2005. Effect of neem cake soil amendment on reduction of damping-off severity and population densities of plant-parasitic nematodes and soilborne plant pathogens. Can. J. Plant Pathol. 27:38-45.

10. Aung, L. H., Flick, G. J., Bluss, G. R., Aycock, H. S., Keefer, R. F., Singh, R., Brandon, D. M., Griffin, J. L., Hovermale, C. H., and Stutte, C. A. 1984. Growth responses of crop plants to fish soluble nutrients fertilization. Bull. 84-9, Virginia Polytechnic Institute and University, Blacksburg.

11. Blok, W. J., Lamers, J. G., Termorshuizen, A. J., and Bollen, G. J. 2000. Control of soilborne plant pathogens by incorporating fresh organic amendments followed by tarping. Phytopathology 90:253-259. 
12. Browning, M., Dawson, C., Alm, S. R., Görres, J. H., and Amador, J. A. 2004. Differential effects of butyric acid on nematodes from four trophic groups. Appl. Soil Ecol. 27:47-54.

13. Browning, M., Wallace, D. B., Dawson, C., Alm, S. R., and Amador, J. A. 2006. Potential of butyric acid for control of soil-borne fungal pathogens and nematodes affecting strawberries. Soil Biol. Biochem. 38:401-404.

14. Bulluck, L. R., III, and Ristaino, J. B. 2002. Effect of synthetic and organic fertility amendments on southern blight, soil microbial communities, and yield of processing tomatoes. Phytopathology 92:181189.

15. Ceci, L. 1975. Fish fertilizer: a native North American practice? Science 188:26-30.

16. Chen, W., Hoitink, H. A. J., Schmitthenner, A. F., and Tuovinen, O. H. 1988. The role of microbial activity in suppression of damping-off caused by Pythium ultimum. Phytopathology 78:314-322.

17. Chu, C.-L., Liu, W.-T., and Zhou, T. 2001. Fumigation of sweet cherries with thymol and acetic acid to reduce postharvest brown rot and blue mold rot. Fruits 56:123-130.

18. Conn, K. L., Tenuta, M., and Lazarovits, G. 2005. Liquid swine manure can kill Verticillium dahliae microsclerotia in soil by volatile fatty acid, nitrous acid, and ammonia toxicity. Phytopathology 95:28-35.

19. Craft, C. M., and Nelson, E. B. 1996. Microbial properties of composts that suppress damping-off and root rot of creeping bentgrass caused by Pythium graminicola. Appl. Environ. Microbiol. 62:1550-1557.

20. DeVleeschauwer, D., Verdonk, O., and Van Assche, P. 1981. Phytotoxicity of refuse compost. Biocycle 22:44-46.

21. El-Tarabily, K. A., Nassar, A. H., Hardy, G. E. St. J., and Sivasithamparam, K. 2003. Fish emulsion as a food base for rhizobacteria promoting growth of radish (Raphanus sativus L. var. sativus) in a sandy soil. Plant Soil 252:397-411.

22. Jeffers, S. N., and Martin, S. B. 1986. Comparison of two media selective for Phytophthora and Pythium species. Plant Dis. 70:1038-1043.

23. Kageyama, K., Ohyama, A., and Hyakumachi, M. 1997. Detection of Pythium ultimum using polymerase chain reaction with species-specific primers. Plant Dis. 81:1155-1160.

24. Hawke, M. A., and Lazarovits, G. 1994. Production and manipulation of individual microsclerotia of Verticillium dahliae for use in studies of survival. Phytopathology 84:883-846.

25. Hoitink, H. A. J., and Boehm, M. J. 1999. Biocontrol within the context of soil microbial communities: A substrate dependent phenomenon. Annu. Rev. Phytopathol. 37:427-446.

26. Kang, H.-C., Park, Y.-H., and Go, S.-J. 2003. Growth inhibition of a phytopathogenic fungus, Colletotrichum species by acetic acid. Microbiol. Res. 158:321-326.

27. Kinnersley, A. M. 2002. Methods of treating plants with glycolic acid. US Patent No. 6432883 B1.

28. Lazarovits, G. 2001. Management of soilborne plant pathogens with organic soil amendments: a disease control strategy salvaged from the past. Can. J. Plant Pathol. 23:1-7.

29. Lazarovits, G., Conn, K. L., Abbasi, P. A., and Tenuta, M. 2005 Understanding the mode of action of organic soil amendments provides the way for improved management of soilborne plant pathogens. Acta Hortic. 698:215-224.

30. Mäder, P., Fliessbach, A., Dubois, D., Gunst, L., Fried, P., and Niggli, U. 2002. Soil fertility and biodiversity in organic farming. Science $296: 1694-$ 1697.

31. Mazzola, M., Brown, J., Izzo, A. D., and Cohen, M. F. 2007. Mechanism of action and efficacy of seed meal-induced pathogen suppression differ in a brassicaceae species and time-dependent manner. Phytopathology 97:454-460.

32. McKellar, M. E., and Nelson, E. B. 2003. Compost-induced suppression of Pythium damping-off is mediated by fatty-acid-metabolizing seedcolonizing microbial communities. Appl. Environ. Microbiol. 69:452-460.

33. Perez, C., Dill-Macky, R., and Kinkel, L. L. 2008. Management of soil microbial communities to enhance populations of Fusarium graminearum-antagonists in soil. Plant Soil 302:53-69.

34. Powelson, M. E., and Rowe, R. C. 1993. Biology and management of early dying of potatoes. Annu. Rev. Phytopathol. 31:111-126.

35. SAS Institute. 1999-2001. SAS for Windows 8 software. SAS Institute, Cary, NC.

36. Sholberg, P. L., Cliff, M., and Moyls, A. L. 2001. Fumigation with acetic acid vapour to control decay of stored apples. Fruits 56:355-366.

37. Tenuta, M., Conn, K. L., and Lazarovits, G. 2002. Volatile fatty acids in liquid swine manure can kill microsclerotia of Verticillium dahliae. Phytopathology 92:548-552.

38. Tenuta, M., and Lazarovits, G. 2002. Ammonia and nitrous acid from nitrogenous amendments kill the microsclerotia of Verticillium dahliae. Phytopathology 92:255-264.

39. Tsao, P. H., and Oster, J. J. 1981. Relation of ammonia and nitrous acid to suppression of Phytophthora in soils amended with nitrogenous organic substances. Phytopathology 71:53-59.

40. Widmer, T. L., Graham, J. H., and Mitchell, D. J. 1998. Composted municipal waste reduces infection of citrus seedlings by Phytophthora nicotianae. Plant Dis. 82:683-688 